\title{
Effect of Reza Shah Modernity on the Political Opposition Development
}

\author{
1Mohammad Reza Motamedi \\ 2Dr. Ali Akbar Amini \\ 1, 2Department of Political Science, Faculty of Law and Political Science, Islamic Azad University, Zahedan Branch, Zahedan, Iran \\ Corresponding Author email: aminpaper@chmail.ir
}

\section{Doi:10.5901/mjss.2016.v7n5s1p84}

\begin{abstract}
Reza Khan, commander of Cossack Brigade based in Qazvin, came to power by coup in 1920, and with the coronation in 1305 brought Qajar dynasty to an end and founded Pahlavi dynasty. He as the first Pahlavi King started a series of planned reforms to establish himself and bring about a secular state and society inspired by the West, especially Ataturk in Turkey. Since then, Islam and Islamic clergies enjoyed power and influence in political and social affairs especially after the effective presence and leadership tobacco and constitutional movements. Reza Shah tries to use sources of progress to bring modernization into people's private life. In 1929, he passed a law that required men to wear foreign outfits instead of traditional and clergy dress, and then to remove hijab was obligatory to women and they were banned from wearing hijab.
\end{abstract}

Keywords: Reza Shah, Modernism, Modernity

\section{Introduction}

Our contemporary history of Iran has always been the scene of battles, victories, defeats and honorable acts of a nation with freedom from domestic and foreign tyranny, the main objective. Trying to prevent the collapse of the country against colonial invasion of Russia, Britain, and The U.S. on one hand and fight against Qajar domestic dictatorship and Pahlavi tyranny on the other hand suggests long-standing efforts of the people of Iran. The coup in 1920 is one of the most important events in the political history of Iran to prepare the ground for the secular state with arrival of Reza Shan to power. Reza Khan took some measures to stabilize him and create a state free of religious influence and Clergymen, inspired by the West, especially Ataturk in Turkey. Although, modernization during this period that corresponded with the western model was incomplete and half-heartedly, the outcome, the secularism was pursued and carried out remarkably.

\section{Problem Statement}

Iranian absolutist government was the government of transition era, the era between traditional era and modern time. Newborn Iran had been formed to some extent under the effect of interactions in Constitutional Era but could not leave its traditional form. The raise of Reza Shah and establishment of Pahlavi Dynasty in 1924 is the beginning point of period of modern absolutist governance. Relative independence of absolutist government led to preparation of renovation project by absolutist government. Political affairs considered some dimensions and priorities within Iran's modernization coordinated with their ideological system while there were different and sometimes in conflict with each other. Modernization of government was at the end of renovation project leading to creation of fundamental changes in structure and function of government and subsidiary institutions. Society modernization was a part of renovation programs that could transform social-traditional structure in educational, cultural, and economic dimensions establishing a society with features of modern societies. In total, it can be stated that "State-building", "nation-building" and "community-building" were three main pillars of renovation project at that time. Reza Shah conducted triple transformations of government, society, and nation largely after coming to power. Hence, this study aims to examine the effect of this trend on formation of domestic opposition.

\section{Research Importance}

Why people were not satisfied despite the efforts of Reza Shah to create modern government, modern military, modern life style, etc.? 
Main objective: study of reasons for the impact of Reza Shah's modernism on creating political opposition in Iran

Secondary objective: study of effective factors in formation of political opposition and reasons for Reza Shah's tendency toward modernism

Research Method: The current study is descriptive-analytical.

Research type: In accordance with research subject and use of obtained results to determine effect on national profits of Iran, this study is a fundamental-applied research emphasizing on its fundamental aspect.

Analysis method: the current study analysis method is the method of "relying on theoretical affairs" to achieve new approaches and extraordinary scrutiny within relevant issues to the importance of reasons for impact of Reza Shah's modernism on formation of modern political opposition in Iran.

\section{Modernism and West Orientation}

Modernism historically is a significance phenomenon and the creator of modern Western civilization. Modernism in political science and sociology is transformation and development of the community. Given the Western civilization, the general development includes politics, economics, ethics, beliefs and values of human social behavior that arises from the material nature. In the East, the idea of progress and modernity emerged in several countries, including Iran, as a new social ideology, in the middle of the nineteenth century and left effects on eastern social life (Amini, 2003:15).

\section{Modernization and Reformation}

The reform and modernization in Iran, although influenced by external factors in dealing with West, the arrival of modernist thought to the country provided a seriously thinking which can be thought of reformers in the field of modernization. The dominant reforms thoughts in the late Qajar to the late Pahlavi is a modernization view although influenced by the ideas of modernity in Europe followed by the changes that emerged from the 16th century to 19 in the western world. Sending students to Europe, as useful and decisive measures by Reza Shah was during his modernity and modernization; it also was common as other affairs of the country, even after Reza Shah and before him from Safavid to Qajar relatively systematically (Bazargan, 2001:83).

\section{Finally, Reza Shah Gained Power}

Reza Shah's mission was to unite country under his own power, without leaving out a single person in North and South and East and West, and from the day of coronation, government offices closed for three days. Reza Shah Tyranny led to reduce the role of government and parliament to the minimum, because the Shah was the highest decision-making authority. No strong and outstanding figure was appointed prime minister, and this position that according to the constitution had the authority to run the country was assigned to Mokhberossaltaneh Hedayat for six years (Mahdavi, 1998: 23).

\subsection{A Look at Reza Shah Policies}

Reza Shah sought to achieve western material progress during the period that ruled as king in Iran, (1925-1941) and even earlier in the period that had gained the title of Sardarsepah through a coup. He repeatedly stated: I will work here and I will build it as in Europe. His goal was to provide people with a tool that will enable them live in an equal condition with any of the European nations. It seems that the main motivation of all social changes and cultural and industrial development of his time he is characterized by this principle (Zargar, 1993: 130).

\subsection{Bases and Principles of Modernity during Reza Shah's Era}

Intellectual effects of Constitutional Movement and the presence of new class of west educated individuals along with the ruling class contributes more to the First Pahlavi inclination toward modernism in Iran than any other factor; establishment of modern army, breaking feudal system, uniformity of cloths, purchasing new weapons, building communicational routes, establishment of military college, establishment of Sepah Bank to organize financial and legal affairs of military forces, approval of mandatory military law, establishment of Civil Registration to identify conscripts of compulsory Military Service, etc. were not rooted in Reza Shah militarism spirit but raised from demands and ideals of intellectuals that considered separation from ruling religious traditions in Iranian community as the only way reaching to west civilization. 
This, in line with developments promoted by Mostafa Kamal in Turkey drew the attention of Shah and his supporters making them adapt anti-religious measurements by Ataturk1.

Reza Shah Cultural reforms and renovations based on three ancient-oriented nationalism (Archaism), modernism, and anti-religiosity. Some of Reza Shah measures in first issue included establishment of new-emerging institutes, expansion of ancient-orientation with emphasis on unity of Aria race, paying attention to history of ancient kings and demonstrating magnificence of imperial states of Iran, establishment of Persian language academy, reconstruction of ancient monuments that were the luminous symbols of the magnificent civilization of ancient Iran from the perspective of Shah, and holding Ferdowsi's millennium celebration. Modernism and weakening religious values was a part of cultural renovation program by Reza Shah's government because he believed that strict religious thought and value bases in the Iranian society was a serious barrier to modernity process; hence, statement of monarchy government began their fight against religion through expanding insouciance and humiliating religious institutes and national traditions. Presence of religious missions, establishment of new schools, return of educated aristocrats from the West, establishment of intellectuality institutes and academies, expansion of promiscuity among women, unveiling the Hijab of women, and changing education system were some activities done and followed seriously at that era (Hesam Al-Din Ashena, 1994, 20-180)

\section{Unveiling Hijab}

Unveiling Hijab did not occur suddenly, or as it is said being formed in his trip to Turkey, but mainly is the phenomenon of familiarity with the West and Western modernism had experienced by those under the influence of western thoughts and lifestyle. While the first signs of unveiling could be found in the Naser Al-Din Shah Qajar court Ballerina dress and then in intellectual circles, but it was recognized in the reign of Reza Shah. Reza Shah Pahlavi after returning from a trip to Turkey decided to unveil in Iran and raised and discussed it cabinet. Forouqi had promised the king implement it (Ghadiani, 2009: 16). Unveiling hijab was carried out on January 7, 1936 and all invited guests participated in the ceremony with their wives unveiled except teachers. Reza Shah participated in the ceremony with unveiled his wife and daughters (Mir, 2013).

\subsection{The policy of Promoting and imposing the European clothes and hats to Iranians}

The other Reza Shah Modernization program with a state history is the compulsory clothing known uniform clothing and Hat change (Maki, 1983:87). Changing hats and clothes was a part of a program sought to make Iranian society resemble the Westerns.

Any community clothing differs in terms of their religious beliefs, national customs and culture, social conditions and climate. Iranian ethnic groups, from early days owned their specific traditional clothing, and Reza Khan made hat cap side common among people with the use of force after returning from a trip to Turkey, to imitate the Ataturk and ordered that Pahlavi hat to be prohibited and outdated, and announced that the men should put on the Shapur hat (Ghadiani, 2009:162).

\subsection{Reza Shah's policy in education}

Reza Shah attitude to provide a modern Iran's made new changes in education and training as one of his goals. The first example is the established a school for the training of employees of the Ministry of Justice in 1922 and the establishment of Military School where Cossack system was merged with that of Qajar. Many public figures who had found that no educational foundation is strong enough without a basic education, insisted that the main attention be paid to elementary level education. This attitude was reflected in some of the first steps of the new regime education plan, including a plan for a period of six years of primary education. The Ministry of Education started to print textbooks in 1928 that were given elementary school students, including co-educational schools free of charge (Banayi, 1961:108).

\subsection{The policy of raising an Army}

Iran's new and ordered army was raised in 1922 by the integration of all troops (Cossacks, gendarmerie and palace

${ }^{1}$ For further study refer to Mohammad Rahim Eyvazi, Social Walks and Shah's Regime, Center for Islamic Documents and Revolution, 2001, \&Hesam Al-Din Ashena, Culture and Propaganda for Government in Iran, Tehran, Imam Sadegh University, 1994 
guards) with the aim of establishing internal order, security and territorial integrity. Reza Khan was the war Minister until 1923, and strengthened his position by relying on the armed forces in different areas. The suppressed all riots and established security. He, relying on its own forces, gradually took the command of the government and all military affairs. Militants followed him and acted as mini- absolute dictators. Police, that also by law was the court bailiff, became the most powerful tool in the hands of Reza Shah for murder, repression and the types of crimes (Sardar Abadi, 1999:9).

Sardar Sepah, integrating Cossacks, state gendarmerie and other forces raised new army in November 16, 1921. The Army constituted five divisions, and thirty thousand officers and soldiers and commander of the five armies were officers who knew themselves responsible for enforcement of war minister policy and Sardar Sepah (Mahdavi, 1998:12). Reza Shah was more concerned about the Army (Reza Shah looked at the Army as the backbone of the new order, and increased defensive budget up to five times between 1926 to 1941 and in the light of compulsory military service, the armed forces rose from 4,000 in five divisions to 127,000 people 18 divisions (Hashem Zehi, 2007:128), nearly half of the country budget spent on Army forces.

\section{Railway Construction}

Railway construction was the most basic aspirations of the Iranian people from the Qajar period with a major role in economic development. But Russia and Britain, who were attempting to weaken Iran, the Iranians did not authorize railway construction. Britain sought to meet their basic needs in the country by south-north railway construction. Ahmed Shah, examining Britain plan stated that railway cannot meet the needs of the nation. He added that desirable railway for Iran is the one that connects the capital to major ports in South and economic zones in East and West. The Pahlavi regime that was basically to meet the needs of the foreigners who helped them come to power started north-south railway construction by putting tax on sugar and ignored West and East of Iran with a priority for railway construction (Najafi et al., 2005: 421: 1384).

\section{Community Opposition to Reza Shah Measures}

In general, social and cultural issues can be classified in three main categories in Reza Shah Era:

1- Imitation of Western customs and traditions: imitation of Western customs was common among the political figures, before the Constitutional Revolution and afterwards, but never a powerful and centralized government enforced the policy of imitation of foreigners in country. Pahlavi dynasty was the first government to enforce this policy in Iran with the support of Britain. British colonialism expected that extremist elements in the Iranian constitution to enforce the same policy, but for many reasons it was not achieved, Reza Shah coming to power, they tried to achieve this goal.

2- Archaism and love for king sprite promotion: Promoting the West orientation leading to rejection of indigenous traditions and customs of the community faced community with humiliating cultural crisis; thus Reza Shah Policy supporters resorted to a sort of Archaism to solve the problem. The purpose of this policy was to promote a spirit of love for king as the king of ancient Persia. This policy led to ignore hundreds of years of post-Islamic Iranian full of national pride, faith and great scientific and intellectual achievements. Reza Shah separated an important part of the country's national history by the adoption of this policy.

3- Opposition to religion and national culture: the two policies of archaism and the West orientation promoted another policy that was the violent struggle with religious and cultural manifestations of the native culture of the country. Shah Reza policies advocates, i.e. The policy designed by foreigners, well knew that they will not be able to achieve both goals as long as religious beliefs and religious scholars are in this country. Thus, Reza Shah started his violent actions for the elimination of religion upon ascending the throne (Ibid: 423).

\section{Conclusion}

Reza Khan gained power by the coup in 1920 in the atmosphere of chaos prevailing in society and the lack of a powerful state with the aim of establishing a strong national government, and was welcomed by scholars and intellectuals, and even some clergies who were exhausted by insecurity and disrespect and the invasion and occupation of foreign forces. Over time, Reza Shah inspired by Western civilization and development, especially Islamic reform by Ataturk in Turkey, opposed to Muslim scholars and religious and political forces to pursue de-Islamification. Accordingly first brought about reforms in Military and administrative system and division of the country to strengthen the foundations of the state and extend the central government authority throughout the country and succeeded in gaining a new administrative system 
and Military forces by promoting a powerful central government. For the first time, relying on strong military and administrative organization under the control of the central government was established all throughout the country. Later, he started the policy of de- Islamification and West orientation and gained controlled over the judicial system and education, which was formed under the laws and religious beliefs. Then he weakened clergies financial affairs pillars by gaining the control of endowment property that were under the control and supervision of clergies. He adopted other reforms to de- Islamification of the society including compulsory military service, the unveiling of women, wearing uniforms for men and women based on Western models deforestation In addition to the reforms that followed a severe blow to the status of religion in society and Clergymen influence on Iran's politics and inflicted more harms in Iran's religious community.

\section{References}

Amini, D. (2003), Challenges of clergies with Reza Shah Regime, Investigating the causes of traditionalism with modernity challenges", Tehran, Sepas publications

Bazargan, M. (2001), Cultural invasion of West and the role of intellectuals affiliated", Volume VIII, Qadr Velayat Institute, Tehran

Banayi, A (1961), "Modernization of Iran", California, Plato Alto

Zargar, AA (1993) "Political relations history between Iran and England in the reign of Reza Shah", Translator: Kaveh Bayat, Tehran, Parvin

Sardar Abadi, A (1999), "Barriers to implementation and policy development in the reign of Reza Shah", Tehran, Islamic Revolution Document Center

Ghadiani, A. (2009), "Cultural coup and Iran civilization in the reign of Reza Shah", Tehran,

Maki, H. (1983), "Iran twenty years history", Tehran, Elmi publications

Mir, O (2013) "Novelty seeking in the first Pahlavi era and society's reaction to it (Clergymen, intellectuals, farmers)", Master's theses, Supervisors prof. Amir Dabiri Mehr, Sistan and Baluchestan University, Faculty of Humanities

Najafi, M \& Haqqani, F (2005), "On the political developments in Iran", Iranian Contemporary Historical Studies

Hashemzehy, N. (2007), "Paradigm of intellectual and social conditions in the wake of the Iranian Revolution (Revolution and the Islamic Revolution)", Tehran, Orouj publications

Mahdavi Houshang, A. (1998) "On foreigb relations of Iran since the Safavid period until the end of Second World War", Tehran, Amir Kabir. 